\title{
Student Elicitation for Estimation
}

\begin{abstract}
A class of bachelor-level students, who were attending lectures in a course on financial crime at the business school in Oslo in the spring term 2017, was asked to fill in a questionnaire with most of the questions we asked our expert panel. When these answers are compared to the expert elicitation earlier in the book, we find that students believe in a slightly higher conviction rate among all those who commit white-collar crime. Our experts believed it was 9.4 percent, while students believe it is 13.5 percent. Rather than focusing on the difference between these estimates, it makes sense to claim that they are similar. Both experts and students believe that the iceberg is many times bigger than what is visible above the surface.
\end{abstract}

Keywords Comparison $\bullet$ Conviction rate $\bullet$ Corruption Detection • Fraud $\bullet$ Gender ratio $\bullet$ Manipulation $\bullet$ Offender groups $\bullet$ Student elicitation $\bullet$ Theft $\bullet$ Victim groups

A class of bachelor-level students, who were attending lectures in an elective course on financial crime at the business school in Oslo in the spring term of 2017, were asked to fill in a questionnaire. The questionnaire had statements derived from the expert elicitation in terms of estimates to calculate the magnitude of white-collar crime.

P. Gottschalk, L. Gunnesdal, White-Collar Crime in the Shadow Economy, https://doi.org/10.1007/978-3-319-75292-1_7 


\section{Fraction of White-Collar Criminals}

We asked students the following question: How large a fraction of all white-collar criminals that commit financial crime in this country do you think is detected and imprisoned? The average answer from the experts was 9.4 percent, or that about one out of ten criminals are caught and sentenced. Students believed slightly more offenders are caught and brought to justice. Their average response was 13.5 percent, which means that they think one out of seven white-collar criminals are caught and sentenced. Their response results in an estimate of 9.3 billion NOK.

\section{Fraction with Probability Distribution}

This was not part of the student survey.

\section{Fraction of OfFender Groups}

Three levels of offenders were defined in this research: (i) top level offenders such as executives and attorneys, (ii) middle level offenders such as investors and accounting managers, and (iii) basic level offenders such as accounting clerks and carpenters. As listed in Table 7.1, respondents believe the fraction of convictions is slightly lower among top level offenders. This approach resulted in an estimate of white-collar crime of the magnitude of 10 billion NOK.

Table 7.1 Estimation based on levels of white-collar criminals Approach 3: Type of white-collar offender

\begin{tabular}{|c|c|c|c|c|}
\hline \multirow[b]{2}{*}{$\begin{array}{l}\text { Level of } \\
\text { white-collar } \\
\text { criminals }\end{array}$} & \multicolumn{2}{|c|}{ Figures from our database } & \multicolumn{2}{|c|}{ Student's estimate } \\
\hline & $\begin{array}{l}\text { Fraction of } \\
\text { population (\%) }\end{array}$ & $\begin{array}{l}\text { Crime amount } \\
\text { (million NOK) }\end{array}$ & $\begin{array}{l}\text { Fraction } \\
\text { convicted (\%) }\end{array}$ & $\begin{array}{l}\text { Sum of money } \\
\text { (billion NOK) }\end{array}$ \\
\hline Top level & 28.4 & 33.0 & 12.5 & 4.8 \\
\hline Middle level & 46.1 & 16.6 & 12.7 & 3.9 \\
\hline Basic level & 25.5 & 9.7 & 13.2 & 1.3 \\
\hline Total & 100 & & & 10.0 \\
\hline
\end{tabular}




\section{Fraction of Crime Categories}

Distinction is made between fraud, theft, manipulation, and corruption. As listed in Table 7.2, students believe theft is most often detected and convicted. Students believe manipulation is most seldom convicted, while experts believe that corruption most seldom leads to conviction. This is an interesting response difference; students may think that manipulation is associated with being smart. This approach resulted in an estimate of white-collar crime of the magnitude of 8.6 billion NOK.

\section{Fraction of Victim Groups}

Distinction is made between the following groups of victims: employers, banks, the tax service, customers, shareholders, and others. As listed in Table 7.3, students believe bank fraud, tax evasion, and insider trading

Table 7.2 Estimation based on categories of white-collar crime

\begin{tabular}{|c|c|c|c|c|}
\hline \multirow[b]{2}{*}{$\begin{array}{l}\text { Category of } \\
\text { white-collar crime }\end{array}$} & \multicolumn{2}{|c|}{ Figures from our database } & \multicolumn{2}{|c|}{ Student's estimate } \\
\hline & $\begin{array}{l}\text { Fraction of } \\
\text { population (\%) }\end{array}$ & $\begin{array}{l}\text { Crime amount } \\
\text { (million NOK) }\end{array}$ & $\begin{array}{l}\text { Fraction } \\
\text { convicted (\%) }\end{array}$ & $\begin{array}{l}\text { Sum of money } \\
\text { (billion NOK) }\end{array}$ \\
\hline Fraud & 42.6 & 25.4 & 15.8 & 4.4 \\
\hline Theft & 4.2 & 4.8 & 17.0 & 0.1 \\
\hline Manipulation & 35.3 & 22.8 & 13.2 & 3.9 \\
\hline Corruption & 17.9 & 2.5 & 16.9 & 0.2 \\
\hline Total & 100 & & & 8.6 \\
\hline
\end{tabular}

Table 7.3 Estimation based on categories of white-collar crime victims

Approach 5: Type of victim

\begin{tabular}{lccccc}
\hline & \multicolumn{2}{c}{ Figures from our database } & & \multicolumn{2}{c}{ Student's estimate } \\
\cline { 2 - 3 } \cline { 5 - 6 } $\begin{array}{l}\text { Category of white- } \\
\text { collar crime victim }\end{array}$ & $\begin{array}{l}\text { Fraction of } \\
\text { population (\%) }\end{array}$ & $\begin{array}{c}\text { Crime amount } \\
\text { (million NOK) }\end{array}$ & $\begin{array}{l}\text { Fraction } \\
\text { convicted (\%) }\end{array}$ & $\begin{array}{l}\text { Sum of money } \\
\text { (billion NOK) }\end{array}$ \\
\hline Employer & 27.9 & 8.7 & & 14.8 & 1.1 \\
Banks & 14.2 & 49.5 & & 17.2 & 2.6 \\
Tax authority & 22.1 & 18.0 & & 16.2 & 1.7 \\
Customers & 16.4 & 17.3 & & 14.3 & 1.3 \\
Shareholders & 7.4 & 29.8 & & 15.2 & 0.9 \\
Others & 12.0 & 6.9 & & 13.5 & 0.4 \\
Total & 100 & & & & $\mathbf{8 . 0}$ \\
\hline
\end{tabular}


achieves a higher conviction rate than employer fraud, customer fraud, and cases involving other victims. Both banks and tax authorities have their own criminal investigation units that are able to provide sufficient evidence so that prosecutors are often able to achieve convictions in court. This approach resulted in an estimate of white-collar crime of the magnitude of 8.0 billion NOK.

\section{Gender Fractions}

Only 7.6 percent of convicted white-collar criminals in Norway are women, while 92.4 percent are men. The rate of detection and conviction may be dependent on gender. Our student respondents think so, as shown in Table 7.4, where respondents believe that only 8.7 percent of female white-collar criminals are caught and brought to justice, while 18.7 percent of male white-collar criminals are convicted. The gender ratio is thus 2.15 in terms of detection (dividing 18.7 by 8.7 ). When we multiply female convicts by the gender ratio, it results in a predicted female fraction of white-collar criminals of 15 percent and a male fraction of 85 percent rather than 7.6 percent and 92.4 percent respectively. This approach resulted in an estimate of white-collar crime of the magnitude of 7.0 billion NOK.

\section{Total Crime Magnitude}

The final estimation technique in this research was to ask the students about a value for the total magnitude of white-collar crime in billions of NOK. The average response was 90.7 billion NOK. Obviously, bachelor-

Table 7.4 Estimation based on gender of white-collar criminals

Approach 6: Gender of white-collar criminal

\begin{tabular}{lcclcc}
\hline & \multicolumn{2}{c}{ Figures from our database } & & \multicolumn{2}{c}{ Student's estimate } \\
\cline { 2 - 3 } \cline { 5 - 6 } $\begin{array}{l}\text { Category of } \\
\text { white-collar crime } \\
\text { victim }\end{array}$ & $\begin{array}{l}\text { Fraction of } \\
\text { population (\%) }\end{array}$ & $\begin{array}{l}\text { Crime amount } \\
\text { (million NOK) }\end{array}$ & $\begin{array}{l}\text { Fraction } \\
\text { convicted (\%) }\end{array}$ & $\begin{array}{l}\text { Sum of money } \\
\text { (billion NOK) }\end{array}$ \\
\hline Women & & & & & \\
Men & 7.6 & 9.0 & & 8.7 & 0.5 \\
Total & 92.4 & 20.4 & & 18.7 & 6.5 \\
\hline
\end{tabular}


level students, most aged 22, have problems with large money values. Some even suggested several hundred billion NOK.

Table 7.5 summarizes all the relevant approaches that resulted in an overall average of 8.5 billion NOK attributed to white-collar criminal damage annually in Norway. Approach 2 was not applied in the student survey, and approach 7 (estimating money values in billions of NOK) resulted in a totally confusing average, and was thus left out.

When this student survey is compared to the expert elicitation earlier in the book, we find that students believe in a slightly higher conviction rate among all those who commit white-collar crime. Likewise, experts believed in an overall average value of 11.9 billion NOK, while the students' value was 8.5 billion NOK. Rather than focusing on the difference between these two estimates, it probably makes more sense to claim that they are similar. Both experts and students believe that the iceberg is many times bigger than what is visible on the surface.

The final question to students in the questionnaire was about their own knowledge: How do you judge your own knowledge of white-collar crime on a scale from 1 (little knowledge) to 10 (a lot of knowledge)? The average response was 4.76 with standard deviation of 1.335 .

Depending on the self-reported knowledge level, it is interesting to study whether there is a significant correlation with the estimated percentages in the above approaches. Statistical analysis reveals that knowledge level is only related to middle level offenders, where respondents who report a higher knowledge level believe in a lower conviction rate for middle level white-collar criminals.

Table 7.5 Student's

estimation based on five approaches

\begin{tabular}{cc}
\hline All approaches combined & \\
\hline Approach & $\begin{array}{c}\text { Student's estimate } \\
\text { (billion NOK) }\end{array}$ \\
\hline $\mathbf{1}$ & 9.3 \\
$\mathbf{2}$ & - \\
$\mathbf{3}$ & 10.0 \\
$\mathbf{4}$ & 8.6 \\
$\mathbf{5}$ & 8.0 \\
$\mathbf{6}$ & 7.0 \\
7 & $(90.7)$ \\
Average & $\mathbf{8 . 5}$ \\
\hline
\end{tabular}




\section{EXPERT-STUDENT COMPARISON}

Why is the iceberg eight or ten times greater than what is visible in Norwegian courts? Why are most white-collar criminals in Norway never convicted? While experts suggest that the main reason is lack of detection, students suggest that the main reason is lack of investigation, as illustrated in Table 7.6.

Table 7.6 Distribution of iceberg elements for white-collar crime

\begin{tabular}{lcc}
\hline & Experts (\%) & Students (\%) \\
\hline Lack of detection & 59 & 15 \\
Lack of investigation & 19 & 29 \\
Lack of prosecution & 8 & 24 \\
Lack of conviction & 5 & 19 \\
Convictions & 9 & 13 \\
Total & 100 & 100 \\
\hline
\end{tabular}

Open Access This chapter is licensed under the terms of the Creative Commons Attribution 4.0 International License (http://creativecommons.org/licenses/ by $/ 4.0 /)$, which permits use, sharing, adaptation, distribution and reproduction in any medium or format, as long as you give appropriate credit to the original author(s) and the source, provide a link to the Creative Commons license and indicate if changes were made.

The images or other third party material in this chapter are included in the chapter's Creative Commons license, unless indicated otherwise in a credit line to the material. If material is not included in the chapter's Creative Commons license and your intended use is not permitted by statutory regulation or exceeds the permitted use, you will need to obtain permission directly from the copyright holder.

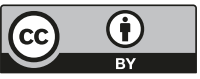

